\title{
Self-Directed Learning and Skills of Problem-Based Learning: A Case of Nigerian Secondary Schools Chemistry Students
}

\author{
Abbas Babayi Abubakar ${ }^{1,2} \&$ Mohammad Yusof Arshad ${ }^{2}$ \\ ${ }^{1}$ Department of Educational Sciences, Mathematics and Multimedia Creative, Faculty of Education, Universiti \\ Teknologi, Malaysia, Malaysia \\ ${ }^{2}$ Department of chemistry, Federal Collage of Education, Yola, Adamawa State, Nigeria \\ Correspondence: Abbas Babayi Abubakar, Department of Educational Sciences, Mathematics and Multimedia \\ Creative, Faculty of Education, Universiti Teknologi Malaysia, 81310 Skudai, Johor, Malaysia. E-mail: \\ abbasbabayi@gmail.com
}

Received: June 1, 2015 Accepted: July 5, 2015 Online Published: November 25, 2015

doi:10.5539/ies.v8n12p70 URL: http://dx.doi.org/10.5539/ies.v8n12p70

\begin{abstract}
The role of chemistry in the development of any society cannot be overemphasized. Chemistry students are therefore expected to acquire flexible knowledge and problem solving skills to facilitate the expected development of our modern society. The purpose of this article is to investigate the roles of teachers and student in the development of self-directed learning and skills in Nigerian Secondary Schools. PBL is a student-centered pedagogy which helps students develop problem solving skills and improved knowledge through self-directed learning under teacher's supervision. It is supported by Cognitive and Constructive psychologists. The learning process in Nigeria schools does not produce students with the required skills and knowledge, because of traditional instructions by teachers, poor learning environment and inadequate learning facilities. This gives a reason for the research. The study used a qualitative approach with explanatory design. Fifteen (15) chemistry students (16 years) and a teacher were purposefully selected in one Senior Secondary School as participants. The participants received 6 weeks of PBL lessons using a topic purification of water. The researchers collected data through observations field notes during the intervention process and also interview a focus group of 5 students after the PBL lessons. The data were transcribed, triangulated and analyzed using content analysis. The results showed students have improved learning and acquisition of problem solving skills including life-long learning and information management due effective self-directed learning activities among them. The researchers therefore recommend the introduction of self-directed learning approach in Nigerian Secondary Schools and other higher educational institutions.
\end{abstract}

Keywords: chemistry, problem-based learning, secondary school, self-directed learning

\section{Introduction}

Professionals working in a complex environment have to be flexible workers, reflective on their competencies and should be able to apply knowledge and skills in a diverse range of real-life situations. Education has the responsibility of training students to become effective professionals. Therefore modern curriculum design should be based on constructive learning theories, focusing on four major principles; The design and learning activities should be relevant to students and connected to real-life and practical situations, learning should be student-centered, collaborative and self-directed (Boucouvalas, 2009; MacDonald \& Isaacs, 2001). As a result of increasing importance of flexible knowledge and problem solving skills in developing a workforce, educational researchers and stake holders become interested in explorations for effective and relevant techniques and methods that might improve learning and development of skills for national development. On that note the national policy on science and technical education in Nigeria directed that graduates should be equipped with flexible knowledge and problem solving skills to enable them perform credibly in different capacities for national development (Federal Republic of Nigeria, 2004). Nigeria therefore needs to adapt new constructive and student-centered learning strategies to produce adequate and effective workforce. Science teachers should make effort to facilitate improved learning and skills acquisitions through students-centered learning strategies to produce competent graduates into work places (Adeyemi, 1990; Nwamno \& Izuagba, 2010). Learning strategies for 21 century education are being practiced in the developed world, for Nigeria to be developed in the year 2020 , 
a shift from traditional to constructive learning approaches are necessary(Abbas \& Arshad, 2014).

Problem-based learning is a student-centered approach where students determined key issues of learning and solve a real-world problem through collaborative and self-directed learning activities under the guidance of a teacher. Focusing on real-life problems and exploration of relevant information across disciplines make students to develop flexible knowledge and effective problem solving skills. PBL process comprises of seven (7) steps as follows: Identify the problem, explore pre-existing knowledge, generate learning hypotheses, and identify learning issues, self-directed study, re-evaluation and application of new knowledge to the problem, assessment and reflection on learning (Barrows, 1996; Walsh, 2005). PBL students are able to apply what they learned in terms of knowledge, reason and solve problems, conduct life-long learning, work in teams, communicate and respect the values and ethics of their professions, because they undergo teaching and learning approaches of practice by doing and teaching others. Therefore the profile of PBL graduates comprises of knowledge, skills and attitudes (Barrows \& Tamblyn, 1980; Mierson \& Freirt, 2004). PBL is a constructive process, motivating and challenging strategy in teaching and learning at all levels of educational institutions and the epicenter of educational research in the 21st century (Surif, Ibrahim, \& Mokhtar, 2013). Researchers reported that PBL is very effective in many areas of learning: It improves the quality of learning because it is multidisciplinary in approach (Savin-Baden, 2000; Hmelo-Silver, 2004). It makes students to be responsible for their learning process as they learn privately with very little assistance from the teacher or guide. Students can transfer learning in terms of knowledge and skills from one situation to another. This provides linkages between classrooms situations and everyday life in the society, the professional life at work places and the acquisition of life-long learning \& information management skills. Students participate fully in collaborative learning activities including, discussions within a group, between groups, presentations of ideas and development of problem solving skills. This creates a friendly learning environment between teachers and their students. PBL developed students' critical thinking to ask more questions, critically look at solutions and conclude on learning issues (Tan \& Arshad, 2014; Kolmos \& Graaff, 2007).

\subsection{Self-Directed Learning}

Self-directed learning required students to plan and manage learning activities, develop solutions or complete projects and personally pursue knowledge and skills. It involve various students-teachers activities and resources, such as self-guided reading, participation in study groups, accessing electronic information and reflective writing; teachers roles include dialogue with learners, securing resources, evaluating learning outcomes, and promoting critical thinking among students. Several researches reported, learner autonomy as an important component of self-directed learning, it does not mean learning in isolation from others. Some determining factors for the success of the learning process have been highlighted as learning environment, learning context, and the connections learners make during their learning (Ponton, 2005; Bouchard, 2009). Although research on self-directed learning has been in place, it context has changed with online learning, because of greater access to technology, and opportunities for more personalized learning experiences and connections to information sources that were not previously available. Educational technology also changes the role of teachers and students, the learning environment, and the structure of traditional schooling. New developments in information and communication technology have put additional expectations on all learners to take more initiatives in their own learning (Posner, 1991; Candy, 2004). Learning institutions have now recognized the importance of self-directed learning as a necessary skill needed for the 21 st century professionals and the need for teachers to enhance students' abilities for accessing self-directed learning (Chou \& Chen, 2008; Kop \& Fournier, 2010). The influence of the Internet on learning gives the opportunities of increase students motivation and the practical justification of the efficiency of ICT, particularly the electronic communication learning platform. Today the internet provides a wide range of opportunities for different aspects of learning including self-directed learning. The global network allows easy access to knowledge and skills considerably as well as learning practically from scratch by means of special services which allow contact of the processs through watching videos(Molchanova, 2015).

\subsection{Teaching and learning in Nigerian Secondary Schools}

However, nowadays traditional lecture methods are still commonly practiced in Nigeria, where teachers dominate the whole learning process with "talk and chalk" and perceived their roles as sole dispensers of knowledge and the student passive listening role as a mark of respect for teachers' authority. This situation does not allow student the freedom to express their ideas and experiences of the new world (Ajaja, 2005; Abbas \& Arshad, 2014). The inability of science teachers to practice students-centered learning methods could be because of the poor learning environment, decayed learning infrastructure, poor science teacher's welfare program and the wrong public attitudes towards teaching as a profession unlike other professionals such as engineers, doctors 
and accountants in the same public service (Ibidapo-Obe, 2007; Das, 2009). As a result of inadequate students learning interactions due to traditional methods, the learning process does not support meaningful learning and development of problem solving skills needed in modern society because passive learning cannot promote the understanding of scientific concepts (Abdullahi, 1982; Baharom \& Palaniandy, 2013). This research therefore investigates how the problem solving skills could be developed through self-directed learning in Nigerian Secondary Schools.

\subsection{Research Objective and Questions}

This research aims to explore self-directed learning and skills acquisition in Nigerian Secondary Schools. It seeks to answer the following questions:

(i) What are the roles of teachers and students in developing self-directed learning?

(ii) What are the roles of teachers and students in developing problem solving skills?

\section{Methodology}

\subsection{Research Design and Sampling Procedure}

This research has a qualitative approach and explanatory design. Fifteen (15) chemistry students with average years of 16 and a teacher with 10 years teaching experience were purposefully selected from a randomly selected Senior Secondary School in Yola South, Adamawa State of Nigeria as the research participants.

\subsection{Intervention Process}

The participants went through self-directed learning process using real-life problems (cholera, pipelines blockages and washing problems) from a Senior Secondary School syllabus study topic purification of water. The participants were divided into three self-directed learning groups. An intervention period of six (6) weeks with three (3) hours learning contact per week was carried out by the researchers with the help of the teacher using PBL module lessons. The module was developed based on Barrows (1996) PBL model.

\subsection{Instrument and Data Collection}

The researchers used observation and interview protocols as research instruments. They collected data during the intervention process through observations field notes on students learning activities and interactions and interview transcript for a focus group of 5 students' using unstructured questions after the PBL module lessons intervention. The data were organized and analyzed using content analysis.

\section{Results and Discussions}

In The data collected were organized and coded into themes using content analysis as follows: Selecting relevant ideas, identifying repeated ideas, organizing the repeated ideas into themes and forming the narrative to describe the research questions.

(i)What are the roles of teachers and students in developing self-directed learning?

\subsection{Self-Directed Learning}

Self-directed learning provides students independent learning with very little teacher support, it gives student the freedom to : Formulate learning goals, assess learning needs, source for learning resources, select the learning strategies, evaluate their learning outcome( Fournier \& Kop, 2010 ; Loyens, Magda, \& Rikers, 2008).

\subsubsection{Students Formulate Their Learning Goals}

(a) Observation field notes reports on students' formulation of learning goals.

Students formulate their learning goals before the process of learning begins. Considering module problem 1(Cholera). The students' dialogue on some teacher facilitation questions; what is the purpose of this learning? What do I want to achieve about cholera" at the end of the learning process? The formulation of learning goal was done with the help of the FILA chart (learning issues and action plan columns) as shown in Table 1. 
Table 1. Students' formulation of learning goals using FILA chart

\begin{tabular}{|c|c|c|c|}
\hline Facts & Ideas & Learning issues/needs & Action plan \\
\hline $\begin{array}{l}\text { The information } \\
\text { obtained from } \\
\text { the problems. }\end{array}$ & $\begin{array}{l}\text { What do we know? } \\
\text { Trying to understand the problem. }\end{array}$ & $\begin{array}{l}\text { What do we need to } \\
\text { know? } \\
\text { The resources you } \\
\text { should find to solve } \\
\text { the problem. }\end{array}$ & $\begin{array}{l}\text { What do we do? } \\
\text { Learning activities to be } \\
\text { conducted to bridge the } \\
\text { learning gaps for problem } \\
\text { solution. }\end{array}$ \\
\hline $\begin{array}{l}\text { Problem } 1 \\
\text { A man is } \\
\text { vomiting, having } \\
\text { diarrhea and is } \\
\text { dehydrated. }\end{array}$ & $\begin{array}{l}\text { The teacher introduced the problems } \\
\text { and asked these facilitating } \\
\text { questions. } \\
\text { What do you know about the } \\
\text { problem? } \\
\text { How devastating is the problem? } \\
\text { Does it affect adult or children? } \\
\text { Students deliberated and concluded } \\
\text { with an idea that: It is a medical } \\
\text { problem known as cholera; it affects } \\
\text { both adults and children but so } \\
\text { devastating on children below } \\
\text { 5years. There is need for solution. }\end{array}$ & $\begin{array}{l}\text { Teacher asked a } \\
\text { question to stimulating } \\
\text { the learning needs: } \\
\text { What do you need to } \\
\text { know about the } \\
\text { problem? } \\
\text { The students discussed } \\
\text { among them and } \\
\text { resolved the need to } \\
\text { answers these research } \\
\text { questions: }\end{array}$ & $\begin{array}{l}\text { Teacher facilitates student } \\
\text { group discussions on the } \\
\text { three research questions } \\
\text { with the aim of solving the } \\
\text { problem. } \\
\text { How do you obtain pure } \\
\text { water for drinking? } \\
\text { How do you maintain } \\
\text { improved environmental } \\
\text { sanitation? } \\
\text { How do you keep good } \\
\text { personal hygiene? }\end{array}$ \\
\hline
\end{tabular}

(b) Interview responses of students on the formulation of learning goals are state below:

Researcher: How do you formulate your learning goal?

Students: "I usually formulate my learning goals...that is aims of learning process". AMCS304.

"I set my learning goals from the FILA chart plan"...AMCS102.

"I asked myself what is the purpose of the learning?AMCS301.

"I plan the learning goal from the FILA chart before the beginning of learning process with the help the teacher AMCS.303.

\subsubsection{Students Assess Their Learning Needs}

(a) Observation field notes reports on students' assessment of learning needs

Students also assess their learning needs before the process of learning begins. Based on problem 2(Blockages of pipes, tabs, shower heads and washing problems). The students discussed on some questions; "what do we need to know" about the problems during learning process? What courses the problems and how to control or solve the problems at the end of the learning process? The formulation of learning needs was also done with the help of the FILA chart the (learning issue / needs column) as shown in Table 2. 
Table 2. Students' formulation of their learning needs using FILA chart

\begin{tabular}{|c|c|c|c|}
\hline Facts & Ideas & Learning issues/needs & Action plan. \\
\hline $\begin{array}{l}\text { The information } \\
\text { obtained from the } \\
\text { problems. }\end{array}$ & $\begin{array}{l}\text { What do we know? } \\
\text { Trying to understand the } \\
\text { problem. }\end{array}$ & $\begin{array}{l}\text { What do we need to } \\
\text { Know? } \\
\text { The resources you } \\
\text { should find to solve the } \\
\text { problem. }\end{array}$ & $\begin{array}{l}\text { What do we do? } \\
\text { Learning activities to be conducted } \\
\text { to bridge the learning gaps for } \\
\text { problem solution. }\end{array}$ \\
\hline $\begin{array}{lr}\text { Problem } 2 & \\
\text { Pipe lines, Tabs, } & \text { Shower } \\
\text { blockages } & \text { and } \\
\text { washing } & \\
\text { difficulties. } & \end{array}$ & $\begin{array}{l}\text { The teacher introduced } \\
\text { the problem and asked } \\
\text { these facilitating } \\
\text { questions. } \\
\text { What do you know } \\
\text { about the problem? } \\
\text { The students critically } \\
\text { discussed and } \\
\text { concluded that: } \\
\text { The problem is due to } \\
\text { water pollution known } \\
\text { as water hardness. It } \\
\text { makes domestic } \\
\text { activities difficult. }\end{array}$ & $\begin{array}{l}\text { The teacher asked to } \\
\text { stimulate learning, } \\
\text { what do you need to } \\
\text { know about the } \\
\text { problem? } \\
\text { The students } \\
\text { collaborated and set } \\
\text { these study questions. } \\
\text { What are the courses } \\
\text { of these blockages and } \\
\text { washing problems? } \\
\text { How does the problem } \\
\text { affect hold activities? }\end{array}$ & $\begin{array}{l}\text { The teacher encouraged students } \\
\text { with a question. } \\
\text { What do you do to solve the } \\
\text { problem? } \\
\text { The teacher encouraged students to } \\
\text { share knowledge and discuss in } \\
\text { groups on the study questions and } \\
\text { proffer a solution on, how to soften } \\
\text { hard water for better house hold } \\
\text { activities. }\end{array}$ \\
\hline
\end{tabular}

(b) Interview responses of students on assessment of their learning needs

Researchers: How do you assess your learning needs?

Students: "I assess my learning needs like ...what and what I need for learning with the guidance of the teacher".AMCS103.

"I plan my learning needs from the FILA chart even before the process". AMCS305.

"What I need to know about the problem at hand to be solved". AMCS205.

"I always assess my learning needs before I browse for information from the internet". AMCS304.

\subsubsection{Student Source for Their Learning Resources}

(a) Observation field notes reports on students' sourcing for their learning resources

Self-directed learning students have the freedom and responsibility of learning. They search for relevant information from the library and internet facilities in the college computer and sometimes using their hand phones to obtain new knowledge. They integrate prior and new knowledge to synthesis solution of the problem.

(b) Interview responses of students on sourcing for their learning resources

Researchers: How do you source for information or learning resources?

Students: "I searched for learning materials from Libraries and internet services in the college and outside for new knowledge to solve the problem"...AMCS203.

"I.... sometimes perform independent reading of materials at home during PBL module self-study period before the next class"...AMCS304.

"I browsed from the internet the information I need for problem solution using my hand phone"...AMCS204.

\subsubsection{Students Choose Their Learning Strategies}

(a) Observation field notes reports on students' choosing their learning strategies

Self-directed learning students have the option of choosing suitable learning strategies they believe can solve the problem involved based on their learning styles (Reference to problem 2; blockages of pipes lines, tabs, shower heads and washing problems). The teacher posed these questions to facilitate student's choice of learning strategies. "What do you do" about the problems? What courses the problems? How do you solve the problems? The students discussed on the questions during a process of choosing their learning strategies with the help of the 
FILA chart (what do we do column) as shown in Table 2.

(b) Interview responses of students on their choice of learning strategies.

Researchers: How do you select your learning strategies?

Students: "I choose the best learning strategies using the FILA chart... what do you do? Column with the teacher guide"...AMCS204.

"I select good learning method that produces best result before the learning process"...AMCS105.

"I look for a better learning strategy, which suit my learning style easy to learn"...AMCS303.

"I independently think of how to go about the learning myself with guide of the teacher"...AMCS102.

\subsubsection{Students Evaluate Their Learning Outcome}

(a) Observation field notes reports on students' evaluation of their learning outcome:

The students were observed assessing their performance during the learning process to make up for any deficiencies of the learning process; they also assess their performance after the learning process to evaluate achievement of objectives and the overall goals of learning. This is done through students' questions and answers session as shown in Table 3.

Table 3. Students' evaluation of their learning outcome through questions/answers session

\begin{tabular}{|c|c|}
\hline Students questions & Students answers \\
\hline $\begin{array}{l}\text { What is the name of the bacteria } \\
\text { in water that courses cholera } \\
\text { AMCS102? }\end{array}$ & $>$ These bacteria are called vibrio-cholerae AMCS101. \\
\hline $\begin{array}{l}\text { How do the bacteria look like } \\
\text { AMCS105? }\end{array}$ & $\begin{array}{l}\text { These bacteria cannot be seen with ordinary eyes but } \\
\text { only with a microscope AMCS103. }\end{array}$ \\
\hline $\begin{array}{l}\text { How does water become hard } \\
\text { naturally AMCS103?. }\end{array}$ & $\begin{array}{l}\text { Water hardness comes from natural occurring calcium } \\
\text { and magnesium salts which are dissolved from the rocks } \\
\text { by rain water flows. Water is harder in limestone areas } \\
\text { than those with insoluble rock such as granite. } \\
\text { AMCS105. }\end{array}$ \\
\hline $\begin{array}{l}\text { Do the bacteria that course } \\
\text { cholera lives only in water? }\end{array}$ & $\begin{array}{l}\text { Based on my ideas the bacteria do not only live in water } \\
\text { but also on some bad foods or fruits, and that house fly is } \\
\text { a vector for transmitting it. Therefore we should also } \\
\text { avoid bad foods and fruits and live in well sanitized } \\
\text { environmentAMCS103. }\end{array}$ \\
\hline $\begin{array}{l}\text { When does water becomes really } \\
\text { hard? }\end{array}$ & $\begin{array}{l}\text { Water become hard if it contained dissolved calcium and } \\
\text { magnesium salts up to } 120-180 \mathrm{mg} \text { per liter AMCS205. }\end{array}$ \\
\hline$>\quad$ How do we soften hard water? & $\begin{array}{l}\text { Hard water can be soften with the use of lime } \mathrm{Ca}(\mathrm{OH})_{2} \\
\text { or soda ash } \mathrm{Na}_{2} \mathrm{CO}_{3} \text {. The calcium and magnesium ions } \\
\text { are precipitated as calcium carbonate } \mathrm{CaCO}_{3} \text { and } \\
\text { magnesium hydroxide } \mathrm{Mg}(\mathrm{OH})_{2} \text { as follows: } \mathrm{AMCS} 104 \text {. }\end{array}$ \\
\hline
\end{tabular}

(b) Interview responses of students on their evaluation of learning outcome.

Researchers: How do you evaluate your learning outcome?

Students: "I assess my learning from time to time because assessment is part of the learning process in PBL”...AMCS104.

"I evaluate my achievement based on the set learning objectives using questions and answers with peers" AMCS301.

"I some time measure the level of my learning looking at what I plan on FILA chart"...AMCS203.

"I evaluate my learning outcome by asking questions: have I achieved the set learning goal? 
Yes...or...No.AMCS301.

The result shows that PBL module lessons develop students' self-directed learning in which they initiate activities and acquired improved learning with minimal teacher support. Self-directed learning students plan and managed learning activities and pursue knowledge and skills on their own. They are involved in various learning activities such as individual and group studies, accessing internet materials and journals writing, interacting with teachers and promoting critical thinking among themselves. It encouraged students to formulate their learning goals, select learning strategies, assess their learning needs, source for learning resources from libraries / internet and evaluate their learning outcome under teacher's guide. It obvious that, giving the responsibility of learning to the learners is an important component of self-directed learning. When students formulate their learning goals, it facilitates the achievement of such goals, similarly students' choice of learning strategies give them an opportunity to choose a strategy based on their learning style, students search for learning resources from libraries and internet yields the most relevant materials across disciplines which provides solutions to the problem. Studentds evaluation of their learning outcome gives the opportunity for improvement of both learning and learning strategy. The result also corresponds with a research report that self-directed learning emphasized learning by doing and helps students to develop their own problem solving skills rather than telling them how to solve the problem. It also gives learners the responsibility and freedom to think creatively, generate and pursue their own learning goals, assess their learning needs, choose appropriate strategies for learning, source for learning materials and evaluate the materials and their learning outcome. Students think, plan and execute effective learning activities and develop life-long learning skills (Brookfield, 1984; Knowles, 1975; Ponton, 2005 \& Bouchard, 2009).

(ii) What are the roles of teachers and students in developing problem solving skills?

\subsubsection{Life-Long Learning and Information Management Skills}

Self-directed learning students have the freedom and responsibility of learning. They choose their learning strategies and search for relevant information on what they want to learn from libraries and internets services. The development in information and communication technology (ICT) has changed the learning environment and created greater access to information sources and more self-directed learning experiences that were not available. Students have more challenges in retrieving information electronically; these new learning activities help students develop life-long learning and information management skills (Posner, 1991; Candy, 2004).

(a) Observation field notes reports on students' development of life-long learning and information management skills.

The students were observed searching for relevant information from the library and internet facilities in the college computer center and sometimes used their hand phones to obtain new knowledge. Students have private reading to collect necessary information and new knowledge; they integrate prior and new knowledge to synthesis solution of the problem.

(b) Interview responses of students on life-long learning and information management activities from the PBL module lessons include:

Researchers: How does PBL module develop your life-long learning skills?

Students: "I have learnt how to source for library materials in the PBL private readings"...AMCS104.

"I also learnt how to browse for journal articles and other materials online using search engine of the internet"...AMCS305.

"I usually have independent study at home to get information for problem solution"...AMCS203.

"Searching for information from the internet give me the ability to manage information more than before" AMCS303.

The result also shows that, PBL module lessons helped students' development of life-long learning and information management skills. They acquire effective knowledge and problem solving skills. The students develop skills for searching and managing information from libraries and internet sources. The knowledge and skills acquired through self-directed learning activities remain useful for life and make PBL module lessons graduates life-long learners. The result is supported by an earlier research report that the developments in the ICT, requires chemistry students to have life-long knowledge and information management skills to be able to overcome routine problems in their everyday life. Self-directed learning process is suitable for life-long learning; it provides the professional needs of graduates in work places because it is a problem solving process (Zakwan, Ismail, \& Razali, 2013; Norman \& Schmidt, 1993). The result is also supported by some research reports that 
students' had improved learning and skills acquisition therefore generally perceived self-directed learning activities as interesting, enjoyable and motivating because it gives them freedom and responsibility for learning through critical thinking and searching for relevant information worldwide. The teacher guides them to search for learning resources from the internet and evaluate the information to provide solution to realize problems in the society (Posner, 1991; Candy, 2004; Meson, 2007).

\section{Conclusion and Implication of the Study}

The introduction of real-life problems to stimulate student self-directed learning and the learning-by-doing approach of the PBL connected knowledge and practice. It also transferred class room experiences to real life situation in the society and enhanced professionalism in workplaces. This research revealed a positive effect of self-directed learning in improvement of learning and skills acquisition in chemistry students. Science teachers should adapt only students-centered learning methods to fully engage students in learning by doing. Therefore the researchers recommended self-directed approach for teaching and learning in Secondary Schools and other higher educational institutions particularly in Nigeria.

\section{Acknowledgements}

We would like to express our profound gratitude's to the teacher and students participants of this study. The school authority and all those who contributed to the success of the study.

\section{References}

Abbas, B. A., \& Arshad, M. Y. (2014). The Need for Problem-based Learning in Nigerian Secondary Schools Chemistry Lessons. A Paper Presented at the $1^{\text {st }}$ International Education Postgraduate Seminar On Innovation, Issues and Challenges for Educational Sustainability. Johor Bahru, Malaysia. 23-24, November, 2014.

Abdullahi, A. (1982). Science Teaching in Nigeria. Ilorin: Atoto Press Ltd.

Adeyemi, M. A. (1990). Cognitive Style: A Variable in Process Skill Development in Science. Nigeria Journal of Education Psychology, 5(1), 45-56.

Ajaja, O. P. (2005). Comparison of the Effectiveness of Three Instructional Methods (Advance Organizer, Discovery and Invention) on Exhibition of Acceptable Laboratory Behaviors. Journal of Vocational Science and Educational Development, 6(2), 16-44.

Baharom, S., \& Palaniandy, B. (2003). Problem-based Learning: A Process for Acquisition of Learning and Generic Skills. Proceedings of the $4^{\text {th }}$ International Research Symposium on Problem-Based Learning (pp. 66-73). Kuala-Lumpur.

Barrows, H. S. (1996). Problem-Based Learning in Medicine and Beyond: A brief Overview. In L. Wilkerson, \& H. Gilselaers (Eds.), Bringing Problem-Based Learning to Higher Education: Theory and Practice. San Franscisco, CA: Jossey-Bass. http://dx.doi.org/10.1002/t1.37219966804

Barrows, H. S., \& Tamblyn, R. M. (1980). Problem-Based Learning: An Approach to Medical Education. New York: Springer Publishing Company.

Bouchard, P. (2009). Pedagogy without a teacher: What are the limits? International Journal of Self-Directed Learning, 6(2), 13-22.

Boucouvalas, M. (2009). Revisiting the concept of self in self-directed learning: Towards a more robust construct for research and practice in a global context. International Journal of Self-Directed Learning, 6(1), 1-9.

Brookfield, S. D. (1984). Self-directed Learning from Theory to Practice. San Francisco: Jossey Bass.

Candy, P. C. (2004). Linking thinking. Self-directed learning in the digital age. Canberra: Australian Government, Department of Education, Science and Training.

Chou, P.-N., \& Chen, W.-F. (2008). Exploratory study of the relationship between self-directed Learning and academic performance in a web-based learning environment. Online Journal of Distance Learning Administration, 11(1).

Das, R. C. (2009). Science Teaching in Schools. New Delhi: Sterling Publishers private Limited.

Federal Republic of Nigeria. (2004). National Policy on Education. Lagos: NERDC.

Fournier, H., \& Kop, R. (2010). New Dimensions to Self-directed Learning in an Open Networked Learning Environment. International Journal for Self-directed learning, 7(2), 1-19. 
Hmelo-Silver, C. E. (2004). Problem-Based Learning: What and how do students learn? Educational Psychology Review, 16, 235-266. http://dx.doi.org/10.1023/B:EDPR.0000034022.16470.f3

Ibidapo-Obe, O. (2007). The Challenges of Teacher Education in Nigeria: The University of Lagos Experience. Paper Presented at the Second Regional Research Seminar for Africa. Organized by UNESCO Forum on Higher Education, Research and Knowledge. Accra.22-24, March.

Knowles, M. (1975). Self-Directed Learning: A Guide for Learners and Teachers. New York: The Adult Education Company.

Kolmos, A., \& Graaff, E. D. (2007). Process of Changing to PBL. In E. Graaff, \& A. Kolmos (Eds.), Management of Change: Implementation of Problem-Based and Project-Based Learning in Engineering (pp. 31-44). Rotterdam: SENSE Publisher.

Loyens, S., Magda, J., \& Rikers, R. M. (2008). Self-Directed Learning in Problem-Based Learning and its Relationships with Self-Regulated Learning. Educational Psychology Review, 20, 411-427. http://dx.doi.org/10.1007/s10648-008-9082-7

MacDonald, D., \& Isaacs, G. (2001). Developing a Professional Identity through Problem-Based Learning. Teaching Education, 1(2), 315-333. http://dx.doi.org/10.1080/10476210120096579

Mason, M. (2007). Critical thinking and learning. Educational Philosophy \& Theory, 39, 339-349. http://dx.doi.org/10.1111/j.1469-5812.2007.00343.x

Mierson, S., \& Freirt, K. (2004). Problem-based Learning (pp. 15-17). American Society for Training and Development. ASTD.

Molchanova, I. I. (2015). Influence of the Internet on Studying English. International Education Studies, 8(1), 133-144. http://dx.doi.org/10.5539/ies.v8n1p133

Norman, G. R., \& Schmidt, H. G. (1993). Where is the Learning in Problem-Based learning? Pedagogue, 4(2), 4-6.

Nwamno, P., \& Izuagba, A. (2010). Teacher Education and Challenges of the Millennium Development Goals. European Journal of Social Sciences, 1(7), 91-95.

Ponton, M. (2005). The relationship between self-efficacy and autonomous learning: The development of new instrumentation. International Journal of Self-Directed Learning, 5(2), 50-58.

Posner, F. (1991). Self-directed learning: The missing ingredient for school reform, Changing Schools, 19(1), $1-8$.

Savin-Baden, M. (2000). Facilitating Problem-based Bearning: The Impact of Tutor's Pedagogical Stances. Journal of Excellence in College Teaching, 11(2/3), 97-102.

Surif, J., Ibrahim, N. H., \& Mokhtar, M. (2013). Implementation of Problem-Based Learning in Higher Education Institutions and its Impact on Students Learning. Proceedings of the $4^{\text {th }}$ International Research Symposium on Problem-Based Learning (pp. 66-73). UTM, Kuala-Lumpur.

Tan, Y. P., \& Arshad, M. Y. (2014). Teacher and Student Questions: A Case Study of Malaysia Secondary School Problem-Based Learning. Asian Social Science, 10(4), 174-182. http://dx.doi.org/10.5539/ass.v10n4p174

Walsh, A. (2005). The Tutor in Problem-Based Learning: A Novices Guide. Canada: McMaster University Press.

Zakwan, F. A. A. Ismail, B. N., \& Razali, W. N. (2013). The implementation of PBL by using FILA Form in measuring Students life-long learning. Proceedings of the $4^{\text {th }}$ International Research Symposium on Problem-Based Learning (pp. 66-73). Kuala-Lumpur.

\section{Copyrights}

Copyright for this article is retained by the author(s), with first publication rights granted to the journal.

This is an open-access article distributed under the terms and conditions of the Creative Commons Attribution license (http://creativecommons.org/licenses/by/3.0/). 